\title{
MEROPLANKTONIC STAGES OF BENTHIC INVERTEBRATES IN LAKE QAROUN (EL-FAYOUM-EGYPT)
}

\author{
Adel A. Mageed \\ National Institute of Oceanography, and Fisheries, 10I Kast AL-Ainy' st., Cairo, Egypt
}

(Received : January 15, 2000)

Key words: Invertebrate larae; polychaete larvae; crustacean nauplius, cirriped and zoea larvae; veliger larvae of Mollusca; Lake Qaroun.

\section{ABSTRACT}

The distribution of mesoplanktonic inverlabrate larvae in Lake Qaroun (EL-Fayoum - Egypt) was studied along a whole year. Monthly collection was carried out at five stations for 12 months, starting in January1996. Numerous larvae of three benthic invertebrate groups; namely Annelida, Crustacea, and Mollusca were obtained. The most dominant larvae were those of Polychaeta followed by Crustacea (mostly Cirripedia). The maximum counts of the larvae were encountered during the hot months.

\section{INTRODUCTION}

Lake Qaroun (in Egypt) is a saline-water lake that lies in ElFayoum Province at $90 \mathrm{~km}$ southern west of Cairo. It is the remnant of an ancient prehistoric lake (Lake Moris). It was originally a fresh water lake connected to the Nile River; as the centuries passed, the lake became separated from the Nile River and its area diminished. Now, it has an area 
of about $222 \mathrm{~km}^{2}$, with maximum depth of about 8 meters at El-Qarn Island (middle of the lake).

The main source of the lake water is the agricultural drainage water which inflows through two main drains (El-Wadi and El-Bats) and twelve other small drains. With time, the lake salinity has increased from $12 \%$ in 1922 up to $30 \%$ in 1985 (Payne, 1986) and reached to about $42 \%$ in 1994 (Sabae, 1996). The salinity is higher at the eastem than the westem side of the lake, as most of the discharged water enters to the east of the lake. The discharge of neighboring agricultural lands contains about 430,000 tons of salts annually (Meshal, 1973). So, salinity of the lake is very important factor affecting the lake ecosystem.

The climate of El Fayoum area is hot and dry (temperature ranges between $18^{\circ} \mathrm{C}$ in winter and $36^{\circ} \mathrm{C}$ in summer). So, the rate of evaporation from Lake Qaroun is high particularly during summer.

The bottom of the lake is muddy loam at the east, as the drainage water carries huge quantities of clay, which is discharged at the east of the lake, whereas the west is mostly sandy (Abdel-Regal, 1995).

Bottom fauna of the lake was studied by Naguib $(1958,1961)$, who stated that, the periodical transport of fishes from the Mediterranean Sea to the lake has simultaneously helped the introduction of smaller marine organisms, in particular molluscs and crustaceans (including barnacles), as well as many larvae of marine benthic invertebrates. He found aiso, some of the benthic crustacean species that became common in the lake such as Balanus pallidus, Gammarus aequicauda, and Sphaeroma serratum. Abdel-Malek and Ishak (1980) found that the benthos of Lake Qaroun is characterized by intensive growth of few species, where the major part is Mollusca, mainly Cerasioderma glaucum. Soliman (1989) indicated that, the increase in the lake salinity would lead to change in the lake bottom fauna. During 1989-1990, 
Fishar(1992) observed that, the most dominant benthos in Lake Qaroun is the annelid Neris diversicolor.

As a result of the increasing salinity, the freshwater fishes such as Tilapia spp., Labeo niloticus, Barbus bynni, Bagrus bayad, and Lates niloticus have disappeared (except T. zilli) (Boraey et al., 1980). To compensate for the loss of freshwater fishes, various species have been introduced successfully such as mullet (Mugil spp.), sole (Solea vulgaris), gill head (Chrysophrys auratus) that began in 1928 from the Mediterranean Sea (Ishak, 1980). Also, the shrimp Metapenaeus stebbingi was transplanted into the lake. The fishery production are $48 \%$ of $T$. zilli, $36.44 \%$ of Shrimp, $7 \%$ of $S$. vulgaris, 3\% of mullets (Mugil spp.) and $5.56 \%$ of others during the period from 1985 to 1990 (Abdel-Razek, 1995). Abdel-Malek (1980) observed that, T. zilli, S. vulgaris, and Mugil spp. feed on Polychaetes and Crustacea.

Except some fragmentary studies on zooplankton of the lake, benthic invertebrate planktonic larvae were so far neglected. So, the present study aimed to examine the monthly variations and spatial distribution of the meroplanktonic larvae of the benthic invertebrates in Lake Qaroun during 1996.

\section{MATERIAL AND METHODS}

Five stations were chosen for sampling the study material from the lake; two at the east, one at the middle, and two at the west (Fig.1). The latitude, longitude, and depths of the stations are shown in Table (1). Samples of planktonic invertebrate larvae were collected monthly from the five localities of the lake during the period from January to December 1996.

Standard plankton net with $55 \mu$ (mesh size) was used for collection of the planktonic larvae of the benthic invertebrates. Three vertical hauls from near bottom to the surface layer at each station were 
collected. The samples were fixed in plastic bottles with $4 \%$ neutral formalin. The larvae were identified, separated from other planktonic taxons, and counted under a binocular (research) microscope in the laboratory. Number of larvae was expressed as number of organisms $/ \mathrm{m}^{3}$.

\section{RESULTS}

Meroplanktonic larvae of Annelida, Crustacea, and Mollusca were represented in the samples. The annual average of the meroplanktonic larvae was 4526 larvae $/ \mathrm{m}^{3}$. Larvae of Annelida were the most dominant in the lake (3096 organisms $/ \mathrm{m}^{3}$ ) followed by larvae of Crustacea, while veliger larvae of Mollusca were rare (363 organisms $/ \mathrm{m}^{3}$ ) as shown in Table (2).

The monthly variations of the total larvae were represented in figure (2). The flourishing period was observed during hot months (from March to October) with maximum counts during May (14958 larvae / $\mathrm{m}^{3}$ ). The distribution of larvae of each group has a special pattern. For polychaete larvae, the highest number was recorded at the eastern side of the lake (station 1) with average number of 5889 larvae / $\mathrm{m}^{3}$, while the lowest counts were recorded in station 4 with average number of 2004 larvae $/ \mathrm{m}^{3}$ Generally, they decreased toward the west (Fig. 3). With regard to monthly variations, the flourishing period of annelid larvae was recorded from May to July (Fig. 4). On the other hand, the lowest number was recorded during cold months (January, February, November, and December).

Regarding the distribution of larvae of Crustacea, it was more or less similar to that of the annelids as shown in Figure (5). The highest number of larvae (1476 organisms $/ \mathrm{m}^{3}$ ) was recorded in station 2 . On the other hand, the lowest counts of larvae were recorded in the western section (station 5). The monthly variations of crustacean larvae showed two peaks during May and September with average numbers of 6288 and 2800 larvae $/ \mathrm{m}^{3}$ respectively. They disappeared during January, 
February, August, November, and with only 59 organisms $/ \mathrm{m}^{3}$ during December (Fig. 6).

The larvae of Mollusca showed their highest counts in station 2 (average of 798 larvae $/ \mathrm{m}^{3}$ ), while the lowest one was recorded in the next station (station 3) with average of 135 larvae $/ \mathrm{m}^{3}$ (Fig. 7). The monthly variations of mollusc veliger larvae showed two peaks, the highest one was during August.(1400 larvae $\left./ \mathrm{m}^{3}\right)$ and the second during April (634 larvae / $\mathrm{m}^{3}$ ). Larvae were not recorded in any site of the lake during October and November (Fig. 8).

\section{DISCUSSION}

According to the classification of Talling and Talling (1965) for the African lakes water, Lake Qaroun currently lies within class III which is characterized with more than 6000 mmhos $8^{-2} \mathrm{~m}^{-1}$ conductivity, and more than $8 \mathrm{meq}^{-1}$ alkalinity. Morales- Baquero ef al (1989) found that the high conductivity lakes contained predominantly benthic and periphytic species. During the present study, various larvae of Annelida, Crustacea (especially Cirripedia) and Mollusca were recorded.

The behavior of these larvae differs from one time to-another, as they swim towards the surface water layer after hatching (Mageed, 1996). When converted to the adult form, they become positively geotactic, so that they swim towards the lake bottom to continue their life cycle in the bottom (Barrington, 1979). So that the nature of bottom sediment plays an important role in the distribution of benthic animals. Wiesser (1959) concluded that the bottom invertebrates were distributed according to the pattern of substrate grades rather than any factor. Wooden (1986), Butman ef al. (1988 a, b) and Butman (1990) concluded that, the selection mechanisms of the larvae probably operate at the time the larvae first reach the bottom, such that the organisms can opt to remain or leave the 
depositional locale. Palmer \& Gust (1985) and Butman et al (1988 a b) added the larvae may redistribute by actively choosing a preferred microenvironment by crawling or short hopping excursions within the depositional locale, by actively swimming above the bottom or remaining on the sediment surface to be resuspended and transported away. These explain why polychaete larvae were concentrated in the east of the lake, where the bottom sediment is muddy loam (Abdel Regal, 1995). The larvae choose the substratum most suitable for settlement. Depth may have an influence on the abundance of annelid larvae. They were mainly attributed to the lowest depth.

Most of the larvae dominated the eastern side of the lake, since most of the drainage water inflows at the east, that becomes more rich with nutrients in addition to the continuous dilution for the salts.

Temperature is known to be an important factor affecting all physical, chemical and biological processes in the aquatic environment (Welch, 1952). It exerts a significant influence on population density of aquatic invertebrates by its direct or indirect impact on all metabolic activities of living organisms (Hickling, 1962). All the planktonic larvae increase with raising temperature but the degree of flourishing varies with different taxa. Dales (1950) showed that spawning of Neris diversicolor (Polychaeta) took place at a time when there was a marked rise in temperature. Fishar (1992) reported that $N$. diversicolor, the main component of Annelida in the lake, increased with increasing of temperature and showed its maximum appearance during warm months. The peaks of its larvae were recorded during the study in May, June, and July. Mason (1986) recorded it in a coastal saline lagoon in east of England.

The highest population density of crustacean larvae (mainly Cirripede larvae) was observed in May. Fishar (1992) recorded the adults in the lake, and Samaan \& Aleem (1972) in Lake Mariut during winter. So, when the temperature increased, the spawning was initiated. 
The increased number of mollusc larvae during March, April, July and August may be due to the breeding behaviour of mollusc species (mainiy C. glaucum). Boyden (1971) showed that the primary spawning of Cerastoderma takes place in late summer and autumn.

It can be concluded that Lake Qaroun is a fertile lake with meroplanktonic larvae of benthic invertebrates, which are currently converted to adults of benthic species. They represent the main food item, in addition to the holoplanktonic species, for the most economic fishs of the lake (Soles vulgaris aegyptiaca, Mugil spp. and Tilapia zilli). The proper ecological management of the lake and transportation of more fish fries to benefit from these organisms leads to increase the lake fish yield.

\section{ACKNOWLEDGEMENT}

First and foremost, I thank prof. Janet Bradford (NIWA, New Zealand) for her substantial suggestions during preparation of the manuscript. I also thank Dr. Fishar (NIOF, Egypt) who gave me a general idea about benthic invertebrates of Lake Qaroun.

\section{REFERENCES}

Abdel-Malek, S. A.(1980). The food and feeding interrelationships of fish in Lake Qaroun, Egypt. J. Ichthyol., 20 (2): 62-66.

Abdel-Malek, S. A.; and M. M. Ishak (1980). Some ecological aspects of Lake Qaroun. Fayoum, Egypt. Part. 2. Production of plankton and benthic organisms. Hydrobiol., 75 (3): 201-208.

Abdel-Razek, F. A. (1995). Abundance and reproductive biology of Metapenaeus stebbingi Nobili, Shrimp in Lake Qaroun, Egypt. Oebalia, 21: 27-36. 
Abdel-Regal, R.M. (1995). Seasonal variations in chemical and minerological properties of Qaroun Lake sediment.Bull. Nat. Inst. Oceanogr. \& Fish., 21: 639-658.

Barrington,E. J. W. (1979). Invertebrate structure and function.ELBS, Book Society and Nelson, Great Britain,1115 pp.

Boraey, F. A. ; M. Kassas and S. I. Ghabbour (1980). Studies on the changes of some ecological factors affecting fish life in Lake Qaroun. The Nile and its environment. Water Supply Manage., 4(1-2): 99-102.

Boyden, C. R. (1971). A comparative study of the reproductive cycles of the cockles Cerastoderma edule and C. glaucum. J.Mar. Biol. Assoc. U.K., 51: 605-622.

Butman, C. A.(1990). Sediment-trap experiments on the importance of hydrodynamical processes in distributing settling invertebrate larvae in near- bottom waters. J. Exp. Mar. Biol. Ecol., 134:3788.

Butman, C. A.; J. P. Grassle and E. J. Buskey (1988a). Horizontal swimming and gravitational sinking of Capitella sp. larvae: Implications for settlement. Ophelia, 29: 43-57.

Butman, C. A.; J. P. Grassle and E. J. Buskey (1988b). Substrate choices made by marine larvae settling in stagnant water and in a flume flow. Nature, 33: 771-773.

Dales, P. R. (1950). The reproduction and larval development of Nereis diversicolor O. F. Muller. J.Mar Biol. Assoc., U.K, 29: 321-359.

Fishar, M. R. A.( 1992) Studies on bottom invertebrats in Lake Qaroun. Egypt. M.Sc Thesis, Fac. Sci., Benha, Zagazig Univ ., 177 pp.

Hickling, S. G. (1962) Fish Culture, Faber and Faber (eds.), London, 295 $\mathrm{pp}$. 
Ishak, M. M.(1980) The fisheries of Lake Qaroun, Egypt. ICLARM. NEWSL. , 3(1): 14 - 29.

Mageed, A. A. (1996). Diumal vertical movements of zooplankton species at Qaroun Lake, El Fayoum-Egypt. Al Azhar Bull. Sci., 7(21): 16211630.

Mason, C. F. (1986). Invertebrate populations and biomass over four years in a coastal saline lagoon. Hydrobiol., 133 (1): 21-30.

Meshal, A. H.(1973). Water and salt budget of Lake Qarun, Fayoum, Egypt. Ph.D. Thesis, Fac. Sci., Alex., 278 pp.

Morales-Baquero, R; L. Cruz-Pizarro, and P.Carrillo (1989). Patterns in the composition of the rotifer communities from high mountain lakes and ponds in Sierra Nevada (Spain). Hydrobiol., 186, 187: 215-221.

Naguib, M. (1958). Studies on the ecology of Lake Qaroun. Part L. Kieler Meeresforsch., 14 (2): 187- 222.

Naguib, M. (1961). Studies on the ecology of Lake Qaroun. Part II. . Kieler Meeresforsch., 17 (1) : 94-131.

Palmer, M. A. and G. Gust (1985). Dispersal of meiofauna in a turbulent tidal Creek. J. Mar. Res., 43: 179-210.

Payne, A. J. (1986). The ecology of tropical lakes and rivers, Johm Wiely \& Sons. Chichester, New York Tornto, Brisbane and Singapore, 300 pp.

Sabaa, S. Z. (1996). Bacteriological and chemical studies on benthic layers of Lake Qaroun, Fayoum, A. R. Egypt. Ph. D. Thesis, Fac. Sci, Tanta Univ., $178 \mathrm{pp}$.

Samaan, A. A. and A. A. Aleem (1972). Quantitative estimation of bottom fauna in Lake Mariut, Bull. Nat. Inst. Oceanogr. \& Fish. 2: 377-397. 
Soliman, G. F. (1989). The hydrology of Lake Qaroun, Fayoum province, Egypt. Part 2. The successive increase of salinity in Lake Qarun. Bull. Nat. Inst. Oceanog. Fish. (Egypt), 15 (1): 93-105.

Talling, J. F. and Talling, T.B. (1965). The chemical composition of African lakes waters, Int. Rev. Ges. Hydrobiol, 50 (3): $421-463$.

Welch, P. S. (1952). Limnology, $2^{\text {nd }}$ ed., New York, Toronto, London, Nc Grow Hill Book Campany. INC. 528 pp.

Wiesser, W. (1959). The effect of grain size on the distribution of small invertebrates inhabiting the beaches of Puget Sound. Limnol. \& Oceanogr., 4: 181-194.

Woodin, S.A.(1986). Settlement of infaunal larval choice. Bull. Mar. Sci. 39: 401-407. 
Meroplanktonic stages of benthic invertebrates of lake Qaroun 37 (El-Fayoum-egypt)

Table 1. Latitude, longitude, and depths (m) of the stations at Lake Qaroun during the study.

\begin{tabular}{|c|c|c|c|}
\hline Stations & Latitude & Longitude & Depth(m) \\
\hline 1 & $29^{\circ} 29^{\prime} 06^{\prime \prime}$ & $30^{\circ} 46^{\prime} 17^{\prime \prime}$ & 4 \\
\hline 2 & $29^{\circ} 29^{\prime} 11^{\prime \prime}$ & $30^{\circ} 41^{\prime} 32^{\prime \prime}$ & 3.1 \\
\hline 3 & $29^{\circ} 27^{\prime} 15^{\prime \prime}$ & $30^{\circ} 36^{\prime} 50^{\prime \prime}$ & 6.2 \\
\hline 4 & $29^{\circ} 26^{\prime} 26^{\prime \prime}$ & $30^{\circ} 31^{\prime} 55^{\prime \prime}$ & 6.8 \\
\hline 5 & $29^{\circ} 25^{\prime} 34^{\prime \prime}$ & $30^{\circ} 28^{\prime} 27^{\prime \prime}$ & 3.5 \\
\hline
\end{tabular}

Table 2. Average numbers (Avg) of meroplanktonic larvae (organisms $/ \mathrm{m}^{3}$ ) of the benthic invertebrates of Qaroun Lake.

\begin{tabular}{|l|l|c|}
\hline \multicolumn{1}{|c|}{ Group } & \multicolumn{1}{|c|}{ Larvae } & Avg. \\
\hline Annelida: & Polychaete larvae & \\
Polychaeta & & 3096 \\
\hline Crustacea: & Nauplius and cirriped larvae & \\
Cirripedia & Zoea larvae & 911 \\
Malacostraca & & 156 \\
\hline Mollusca: & Veliger larvae & 363 \\
\hline Total & & $\mathbf{4 5 2 6}$ \\
\hline
\end{tabular}




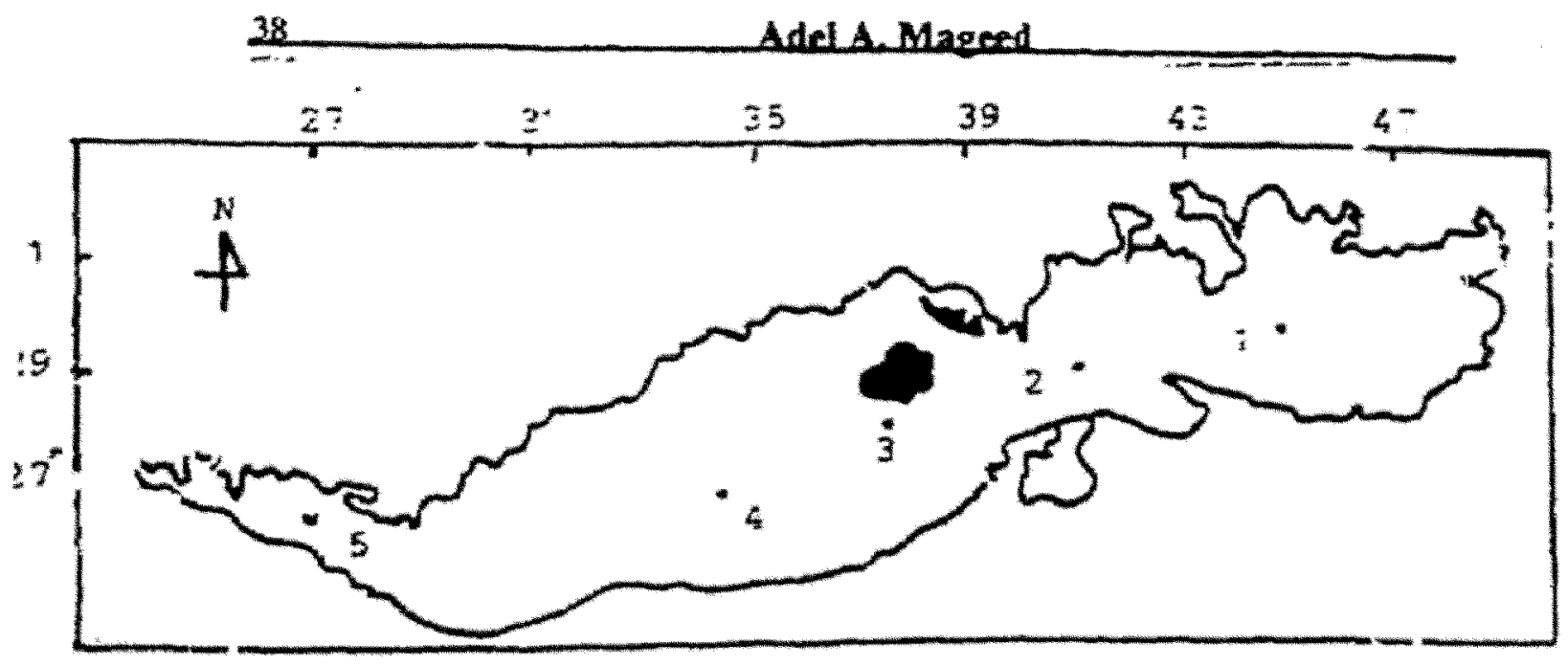

Fig. 1. Showing sites of sampling at Lake Qaroun.

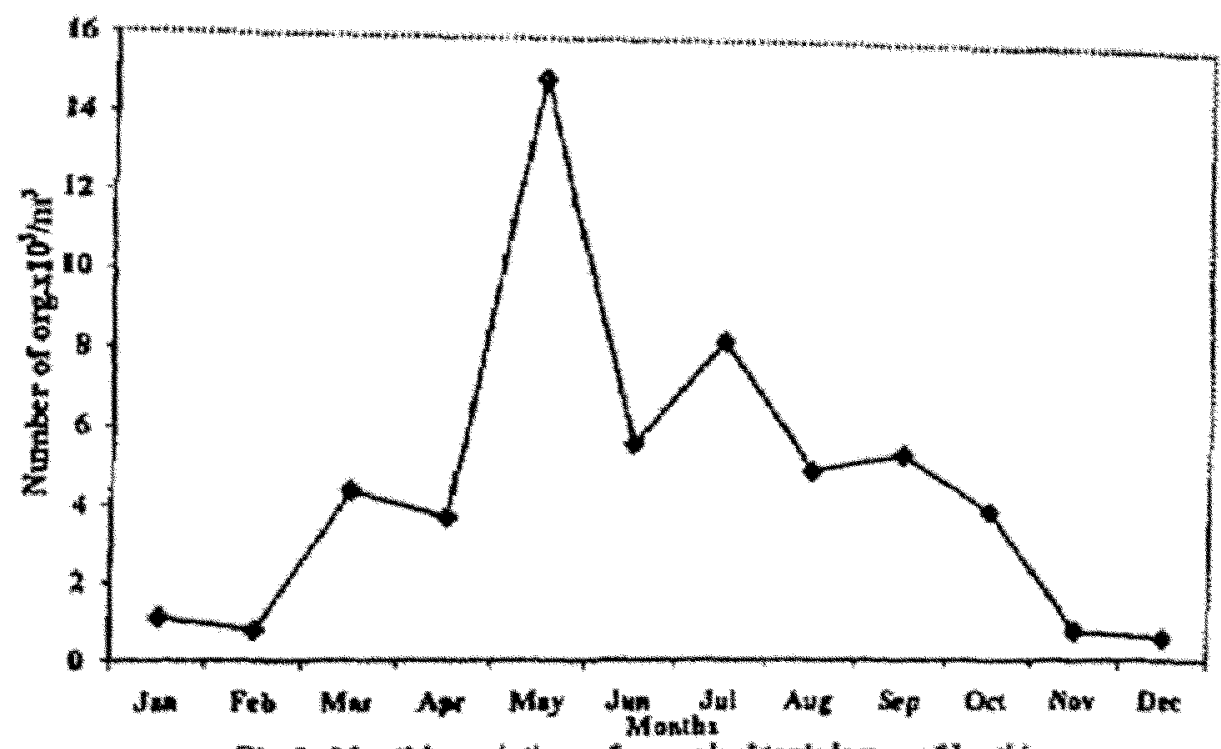

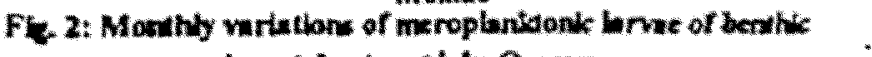
invertebraice at Lale Owroum. 
Meroplanktonic stages of benthic invertebrates of lake Qaroun 39 (El-Fayoum-egypt)

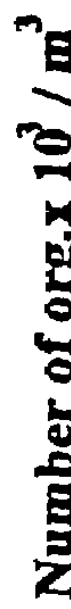

告 $\left.\begin{array}{l}8 \\ 6 \\ 4 \\ 2 \\ 0\end{array}\right]$ 1<smiles>[CH]1[CH]CC1</smiles><smiles>C1CCC1</smiles> 


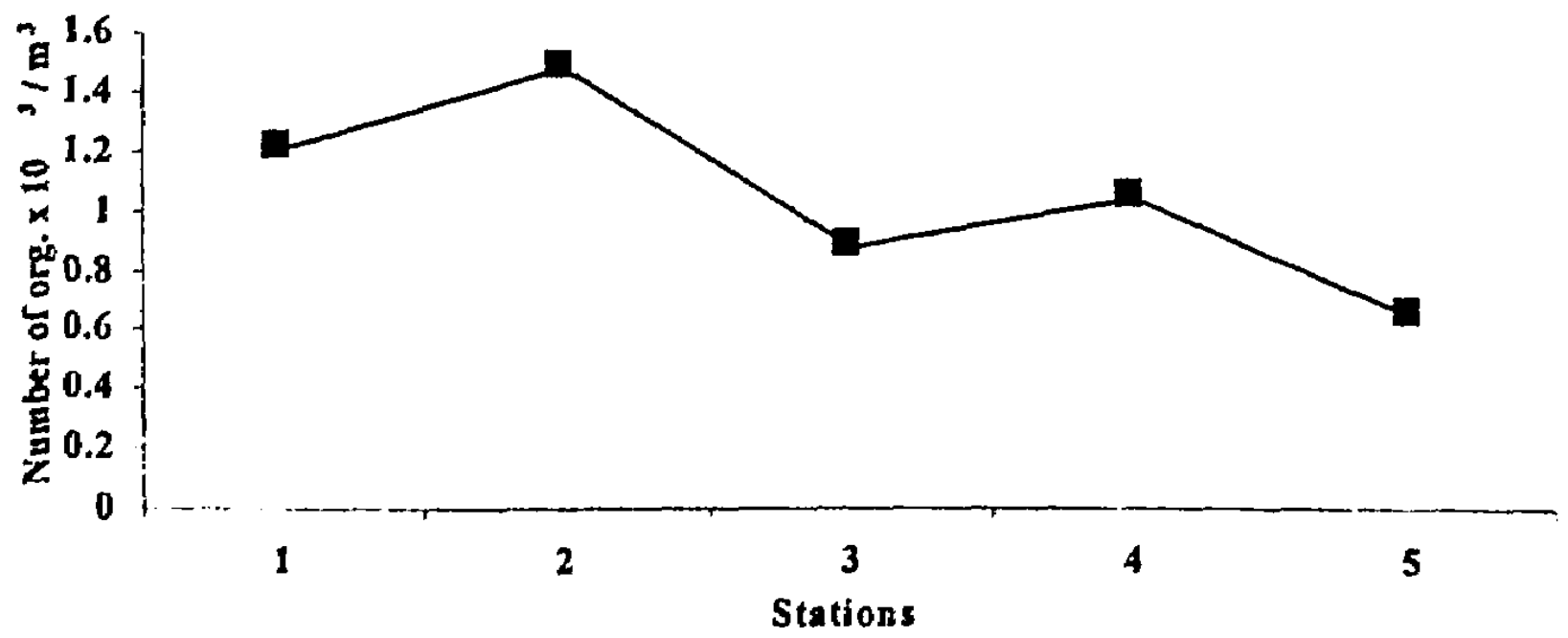

Fig. 5. Distribution of crustacean larvae (organisms $/ \mathrm{m}^{3}$ ) recorded during the study at Lake Qaroun

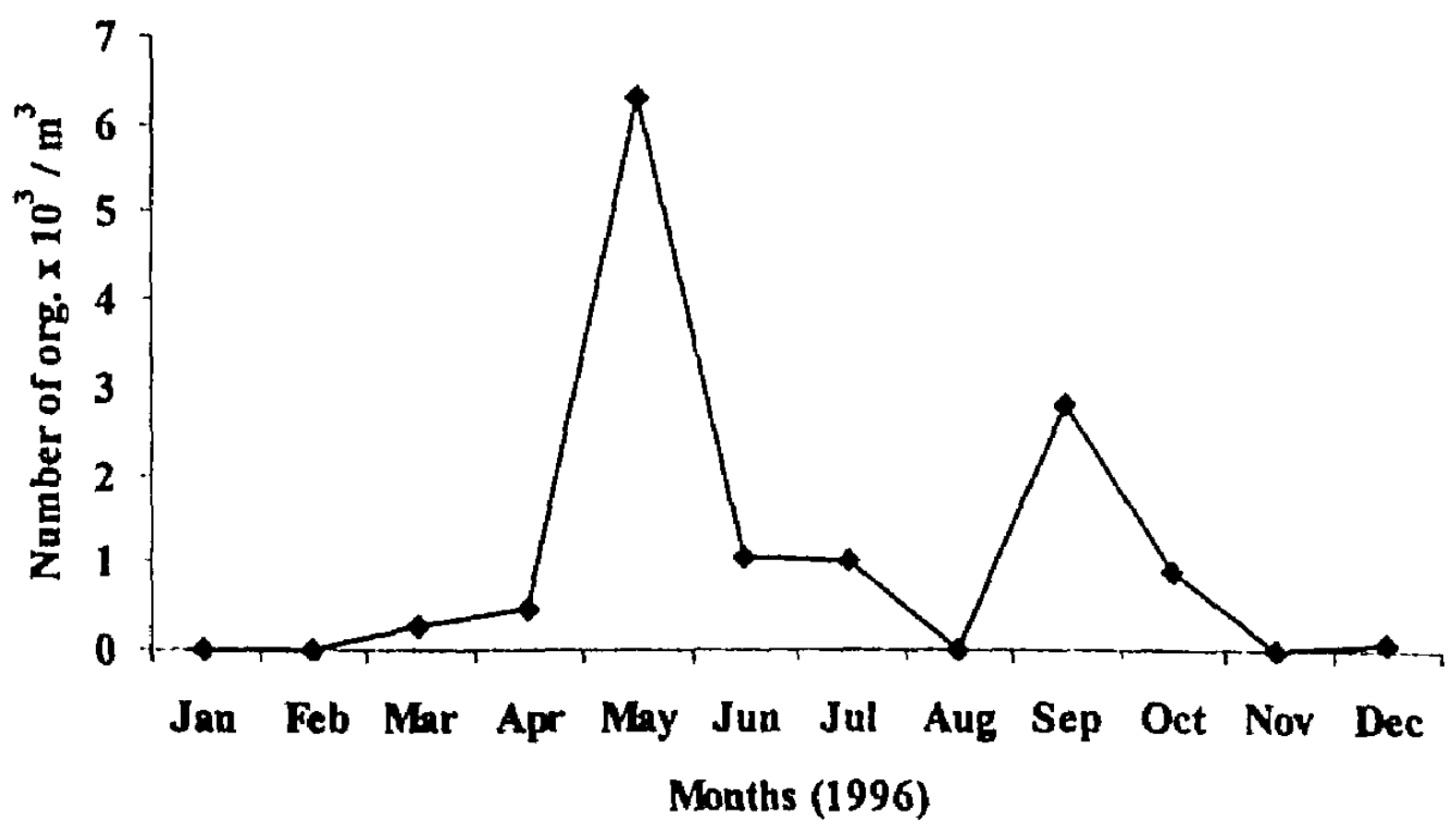

Fig. 6. Monthly variations of crustacean larvae (organisms $/ \mathrm{m}^{3}$ ) recorded during the study at Lake Qaroun 
Meroplanktonic stages of benthic invertebrates of lake Qaroun 41 (El-Fayoum-egypt)

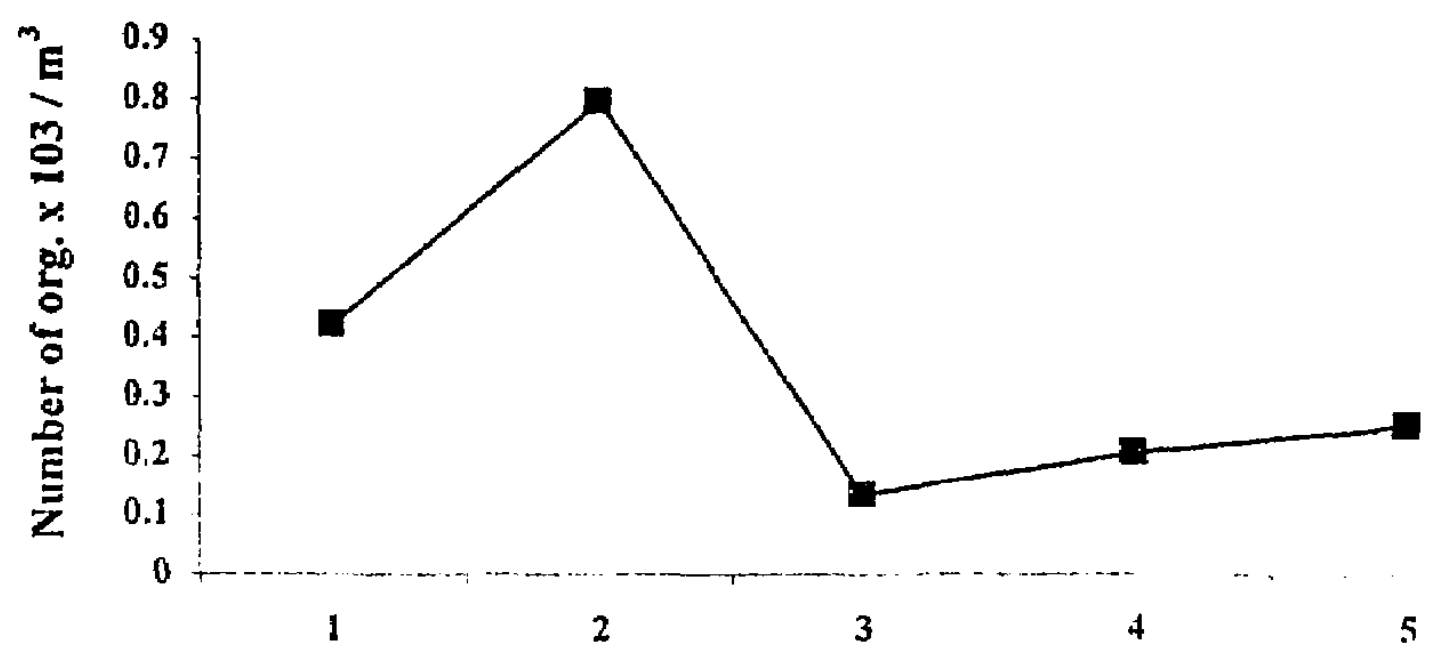

Fig. 7. Distribution of Iarvae of Mollusca (organisms $/ \mathrm{m}^{3}$ ) recorded during the study at Lake Qaroun

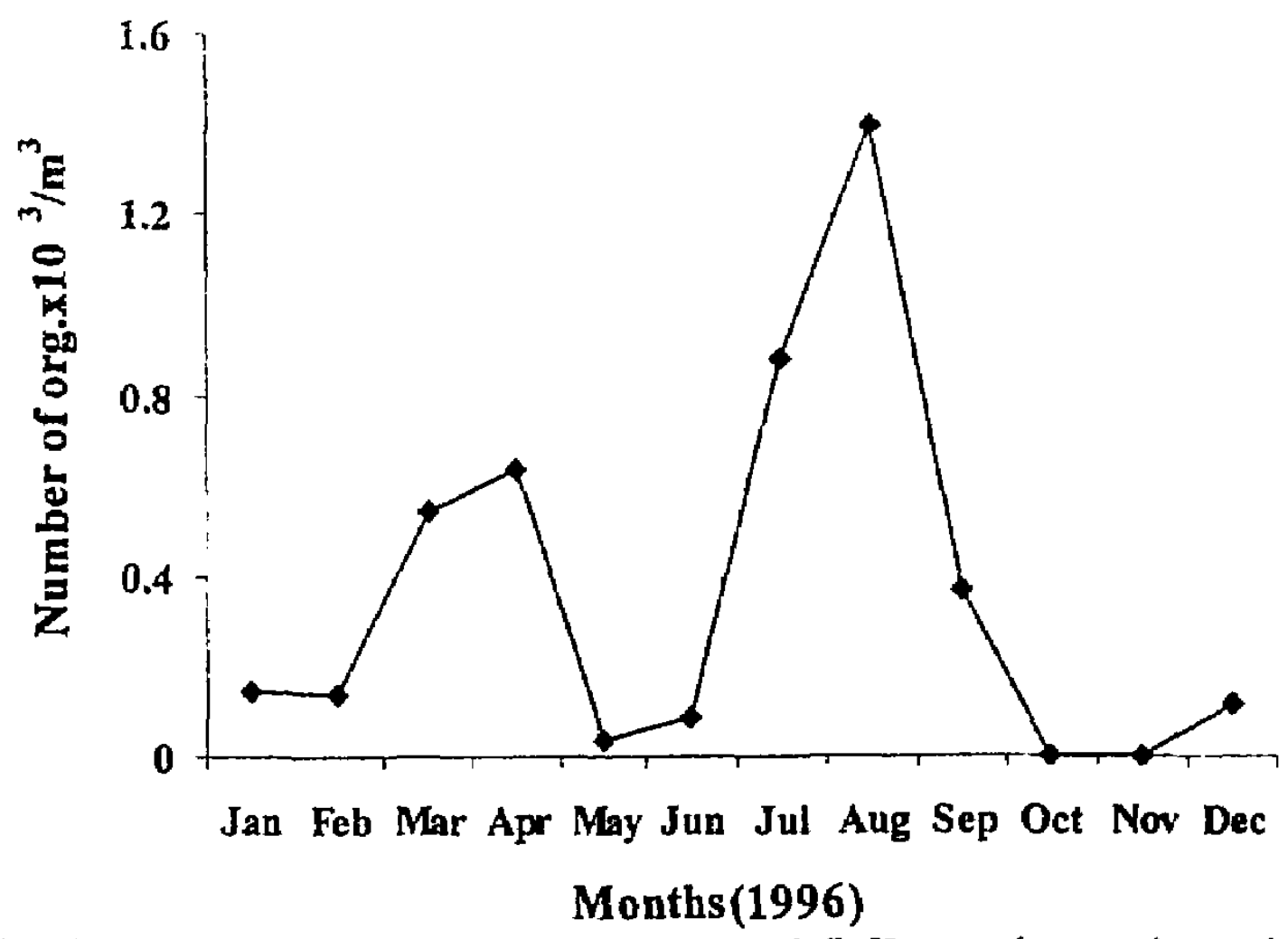

Fig. 8. Monthly variations of larvae of Mollusca (organisms / $\mathbf{m}^{3}$ ) recorded during the study at Lake Qaroun 